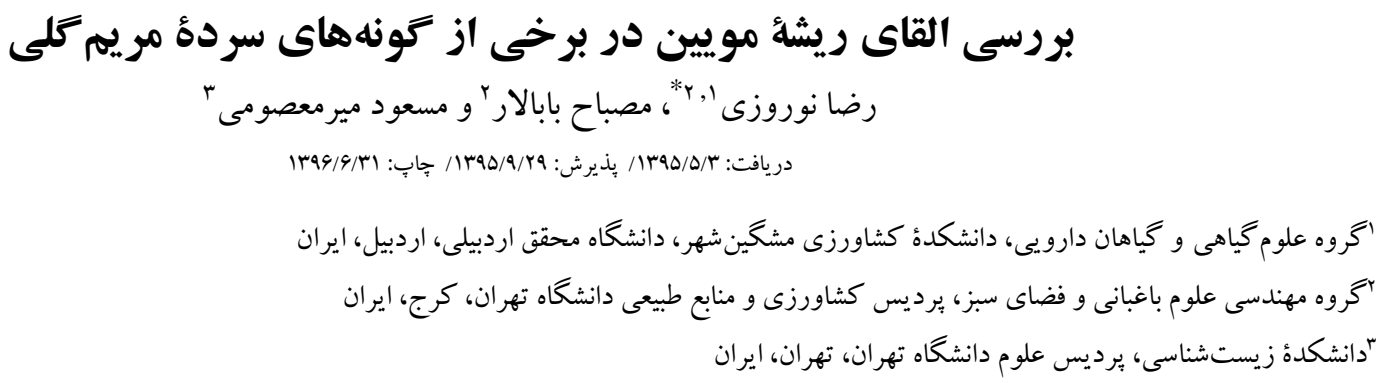

reza.norouzi@uma.ac.ir :مسئول مكاتبات"

جكيده. القاى ريشٔ مويين در گياهان از طريق ورود T-DNA از يلاسميد Agrobacterium rhizogenes به زنوم سلولهاى گياهى انجام مىشود. مطالعه

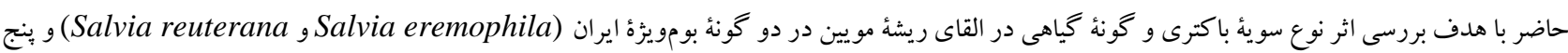

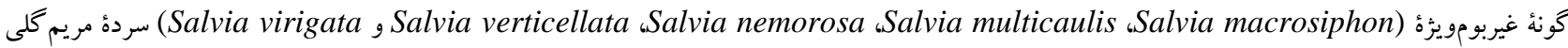

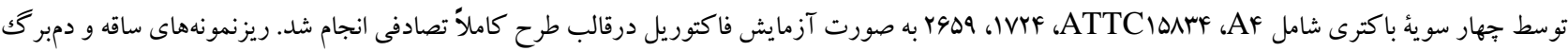

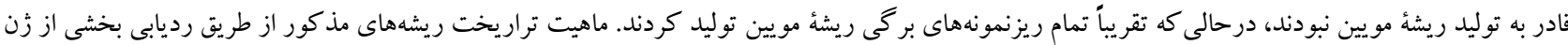
أم COl C

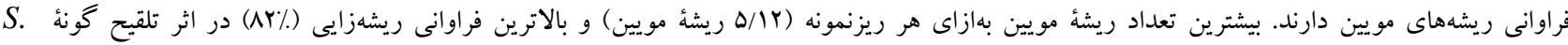

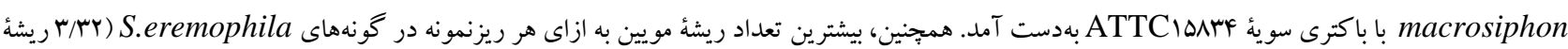

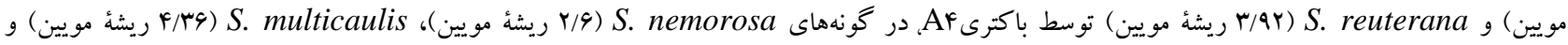
Serticillata

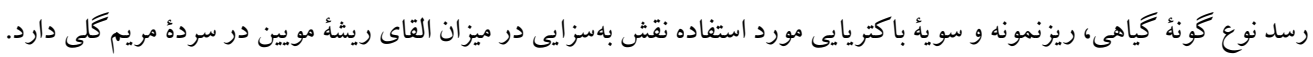
وازههاى كليدى. Agrobacterium rhizogenes، ريشهاى تراريخت، ريزنمونهُ بركى

\title{
Investigation of hairy root induction in some Salvia L. species
}

Reza Norouzi ${ }^{1,2 *}$, Mesbah Babalar ${ }^{2}$ \& Masoud Mirmasoumi ${ }^{3}$ Received 24.07.2016/ Accepted 19.12.2016 / Published 22.09.2017

${ }^{1}$ Meshginshahr Faculty of Agriculture, University of Mohaghegh Ardabili, Ardabil, Iran ${ }^{2}$ University College of Agriculture and Natural Resources, University of Tehran, Karaj, Iran ${ }^{3}$ Department of Botany, College of Sciences, University of Tehran, Tehran, Iran *Correspondent author: reza.norouzi@uma.ac.ir

Abstract. Hairy root induction in plants is the result of the insertion of T-DNA from Agrobacterium rhizogenes into the plant genome. The present study was conducted to investigate the effect of bacterium strain and plant species type on hairy root induction in two endemic (Salvia eremophila and S. reuterana) and five non-endemic (S. macrosiphon, S. multicaulis, S. nemorosa, S. verticellata and S. virigata) Salvia by four bacteria strains including 1724, 2659, ATCC15834 and A4. Petiole and stem explants were not capable of inducing hairy roots, while almost all leaf segments produced it. Confirmatory studies were carried out by direct detection of inserted rol C by the PCR. The results showed that different Agrobacterium rhizogenes strain and Salvia spices had significant effect on hairy roots number and frequency. The infection of $S$. macrosiphon via A. rhizogenes strain ATCC15834 showed the highest number of infected roots per explant (5.12 hairy roots) and root frequency (82\%). The highest number of hairy root per explant in $S$. eremophila (3.32 hairy roots) and S. reuterana (3.92 hairy roots) were achieved by inoculation with strain A4. Strain 2659 produced the highest hairy roots number in $S$. nemorosa (2.6 hairy roots), S. multicaulis (4.36 hairy roots) and $S$. verticillata (5 hairy roots). Also hairy roots formation occurred at the highest number in $S$. virigata (3 hairy roots) with infection by strain ATCC15834.

Keywords. Agrobacterium rhizogenes, transformed root, leaf explant 
و استفادهاى متعدد دارويى و درمانى دارند و در طب سنتى به منظور درمان اخزما، سرماخوردگى، برونشيت، ناراحتىهاى Li et al., ) كوارشى، گلودرد و سل مورد استفاده قرار مى گيرند 2013). همجنين، مطالعات امروزى حاكى از خو اص ضد باكترى، ضد قارجى، ضد تومورى، آنتى اكسيدانى و ضدالتهابى گونهاى مختلف سرده مريم گلى است (Kamatou et al., 2008). اين

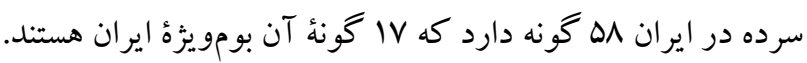
كشور بهناور ايران كه داراى اقليمهاى متنوعى است از لحاظ تعداد گونههاى گياهى بسيار غنى است و در اين ميان گونهاى مختلف سردهُ مريم گلى از گونهاى بارز بوشش گياهى ناحيه ايرانو-تورانى محسوب مىشود : Rabbani et al., 2005;

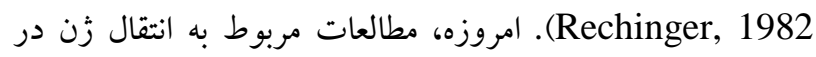
كياهان توسط A. rhizogenes و توليد ريشههاى مويين با هدف توليد متابوليتهاى ثانويه با ميزان بالا بسيار گسترش يافته است. اين درحالى است كه علىرغم تنوع گونهاى قابل ملاحظة سردة مريم كلى در كشور ايران، تاكنون هيج مطالعهاى در زمينه القاى ريشههاى مويين در اين كونها صورت نكرفته است. بنابراين، هدف مطالعهُ حاضر، بررسى القاى ريشه مويين در برخى گونهاى

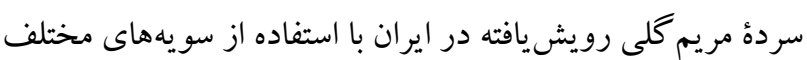

\section{A. rhizogenes}

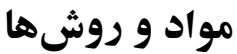
مواد كياهى بذرهاى هفت گونهُ مريم گلى شامل دو گونهُ بومويزٔه ايران و ينج كونهُ غيربومويزٔه ايران، از بانكك زن منابع طبيعى سازمان تحقيقات جنگل ها و مراتع كشور و همجنين از هرباريوم دانشكده زيستشناسى دانشخاه شهيدبهشتى تهيه شد (جدول ()). بهمنظور توليد كياهجههاى استريل بذرها بِ بساز ضدعفونى سطحى توسط اتانول V درصد و محلول ينج درصد هيبو كلريتسديم (هر كدام به مدت ل. •ا دقيقه) و شستوشو با آب مقطر در محيط كشتهاى MS فاقد هورمون و حاوى ب درصد درصد ساكارز، كشت و تا زمان جوانه زنى در اتاقك رشد تاريكك با دماى بهمض ظهور كياهجه، ظروف كشت به دورهُ نورى 19 ساعت روشنايى (با شدت نور .أ لو كس) و ^ ساعت تاريكى منتقل
مقدمه

كياهان عالى از زمان حضور انسان در كره خاكى كليد رفاه او بودهاند. بشر، در طول قرنها همواره از مواد دارويى موجود در بيكره گياهان براى تأمين سلامتى و درمان بيمارىهاى خود استفاده كرده است. ويز گیى دارويىبودن گياهان بهواسطة متابوليتهاى ثانويهاى است كه طى واكنشهاى متابوليسمى در بيكرة آنها توليد مىشوند و تجمع مىيابد (Hussain et al., 2012). ريشءٔ برخى از خانو ادههاى گياهى محل بيوسنتز يا تجمع متابوليت هاى ثانويهاى

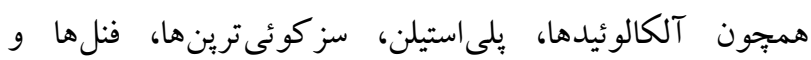
فلاونوئيدهاست. همجنين، اين تركيبات مىتوانند در ريشهاى مويين اين كياهان نيز توليد شوند (Sharma et al., 2013). امروزه، كشت ريشههاى مويين، بهدليل رشد سريع، ثبات زنتيكى، مرفولوزيكى و بيوشيميايى، نداشتن زمين گرايى، سهولت نخهدارى و قابليت رشد در محيطهاى كشت فاقد هورمون و قابليت توليد بسيارى از متابوليتهاى ثانويه، منبع مناسب و ارزشمندى جهت توليد تركيبات شيميايى گياهى، متابوليتهاى ثانويه در مقياس Shanks \& Morgan, ) وسيع و آنتى بادىهاى مونو كلونال است زاز اين ريشها تراريختشدن بافتهاى گياهى توسط باكترى گرم منفى و خاكزى Agrobacterium rhizogenes بهوجود مى آيند. اين باكترى با واردكردن يكك قطعه T-DNA از پِاسميد القاكننده ريشه (يلاسميد Ri)، مشتمل بر تجهار زن به rol C ،rol B rol A و rol D به زنوم سلولهاى گياهى و بيان بايدار زنهاى rol در سلولهاى گياه، بهظهور فنوتيٍ ريشهاى مويين منجر مىشود (Bulgakov, 2008; Chaudhuri et al., 2005). فرايند تراريخت شدن بافتهاى گياهى و القاى ريشه مويين در آنها تحت تأثير عوامل مختلفى قرار مى گيرد كه شامل گونه، سن و نوع بافت كياهى و وضيعت فيزيولوزيكى آن، سويه و غلظت سوسيانسيون باكتريايى است. بنابراين، بهمنظور بهينهسازى توليد ريشهاى مويين، بايستى برهم كنش سويههاى مختلف باكترى و زنو تيڤِهاى كياهى تحت بررسى قرار گيرد ) Hu Du, 2006; Kumar et .(al., 2006 سرده Salvia (مريم كلى) متعلق به تيرهُ نعنائيان است و بالغ بر 9.. (Barrett et al., 2000). كونهاى اين سرده اغلب معطر هستند 
جدول 1- مشخصات هرباريومى گياهان تحت آزمايش.

Table 1. Herbarium characteristic of studied plants.

\begin{tabular}{|c|c|c|c|c|}
\hline ت توضيحات & شماره هرباريومى & محل جمع آورى & 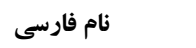 & كونهُ كياهى \\
\hline بومويثه ايران & r9099* & جيرفت-كرمان، ارتفاع: V. Va & مريم تلى بيابانى & S.. eremophila \\
\hline غيربومويثه ايران & r9.19* & روستاى نعمت آباد، قروه- كردستان، ارتفاع: به ب متر & 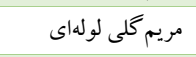 & S. macrosiphon \\
\hline غيربومويثه ايران & 191V^* & سر حشمه، شهميرزاد- سمنان، ارتفاع: ...T متر & 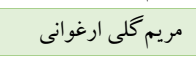 & S. multicaulis \\
\hline غيربومويثه ايران & $\wedge \Delta \cdots ৭ \wedge \Delta_{* *}^{*}$ & جادة جالوس، ميدانكك- البرز، ارتفاع: YYY TI & 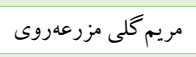 & S. nemorosa \\
\hline 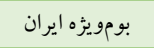 & $\wedge \Delta \cdot 1 \ldots 1^{* *}$ & جادة جالوس، ييلقان - البرز، ارتفاع بوع1 متر & مريم كلى اصفهانى & S. reuterana \\
\hline غيربومويثه ايران & $\wedge \triangleright . . ৭ ৭ 9 * *$ & جادة حالوس، بين آسارا و ماهان- البرز، ارتفاع: MAF & مريم كلى بنفش & S. verticellata \\
\hline غيربومويزه ايران & rAYq১* & نجف آباد - اصفهان، ارتفاع: 19Fr متر & 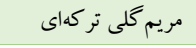 & S. virigata \\
\hline
\end{tabular}
"Obtained from the Research Institute of Forests \& Rangelands, " University.

(Doyle \& Doyle, 1987)

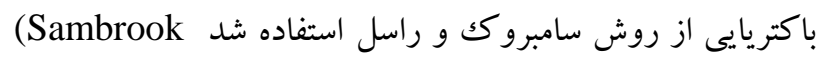
\& Russell, 2001)

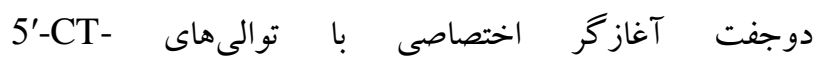
5'-TGCTTC- , CCTGACATCAAACTCGTC-3' rol براى تكثير قطعهاى از زن GAGTTATGGGTACA-3' PCR وارد واكنش PCR (ه人9bp) C

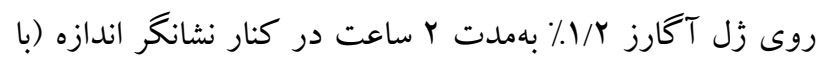
اندازه •ه جفت بازتوليد شركت Fermentas) الكتروفورز شدند.

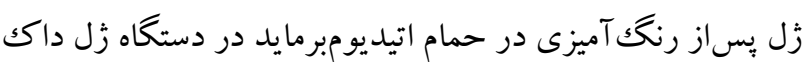
مدل Gel Logic 212 Pro مشاهده شد.

\section{محاسبات آمارى دادهها}

بررسى القاى ريشٌ مويين بهصورت آزمايش فاكتوريل درقالب

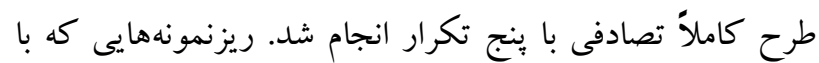

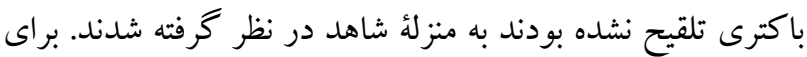

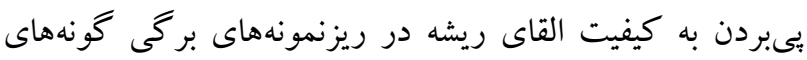

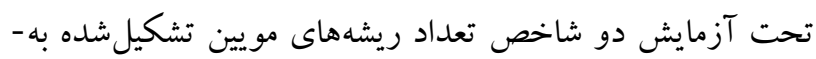

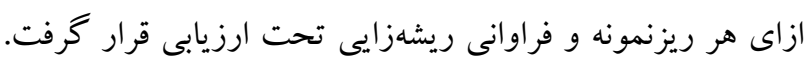

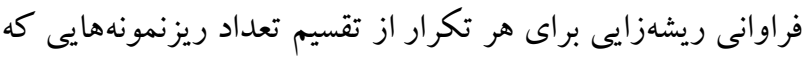
ريشهُ مويين توليد كرده بودند بر تعداد كل ريزنمونههاى تلقيحشده توسط باكترى در هر يترى برحسب درصد بهدست آمد. تجزيه و

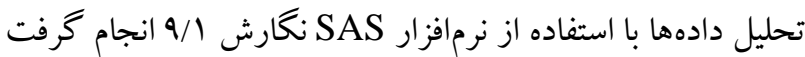

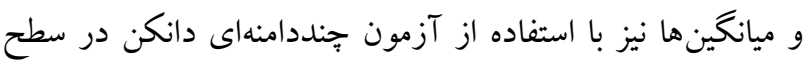

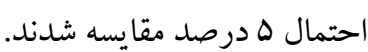

\section{آمادهسازى سوسبانسيون باكترى}

بهنظور القاى ريشٔ مويين از جهار سوية A. rhizogenes شامل

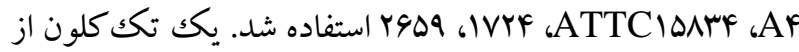

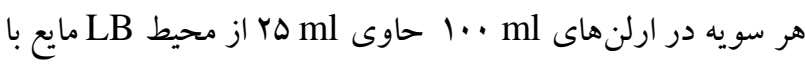

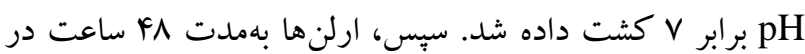
تاريكى روى شيكر با سرعت rpm ..1 در دماى بـ

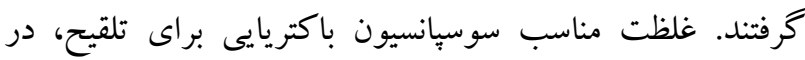

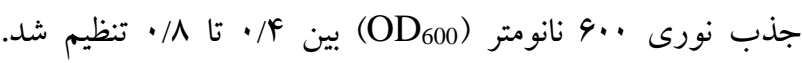

آمادهسازى و تلقيح ريزنمونهها

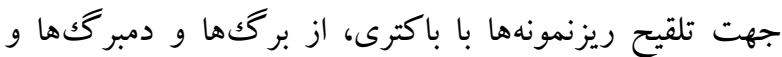

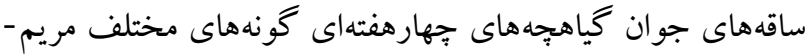

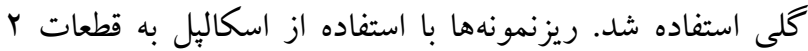
سانتىمترى تقسيم شده و بهمدت • ا دقيقه در سوسيانسيون باكترى غوطهور شدند. آن كاه، ريزنمونها روى محيط كشت جامد عارى از هورمون قرار گرفتند و به اتاق رشد با دماى

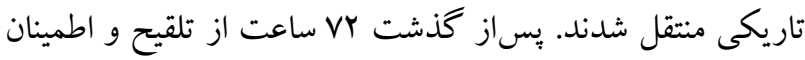

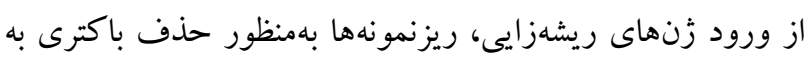

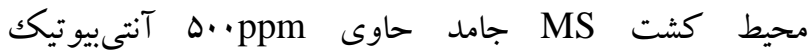

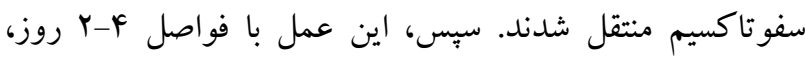

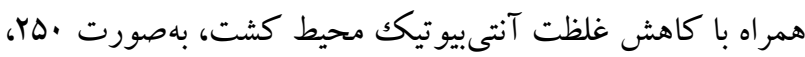

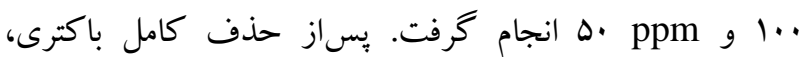

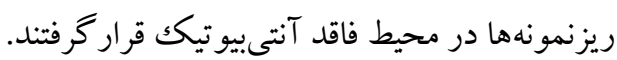

بررسى ماهيت تراريخت ريشه هاى مويين

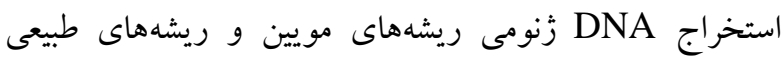
غيرتراريخت (شاهد منفى) بهروش دويل و دويل انجام بذيرفت 
(Y/9/Y ريشه بهازاى هر ريزنمونه) و S. verticillata (ه ريشه بهازاى

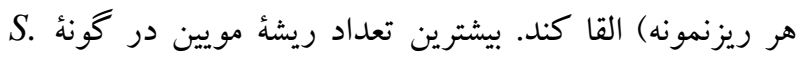
virigata ATTCIQAry

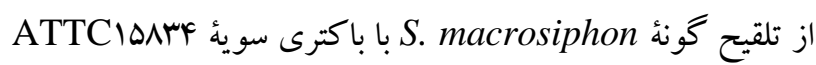

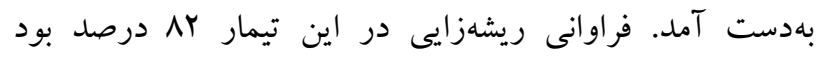

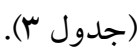

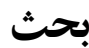
در اين مطالعه ريزنمونههاى تهيهشده از ساقه و دمبرگك قادر به توليد ريشهٔ مويين نبودند و قهوهاى و سياه شدند. تحقيقات بيشين

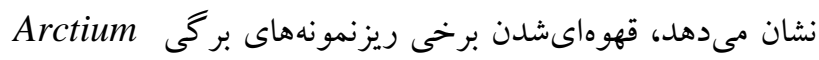

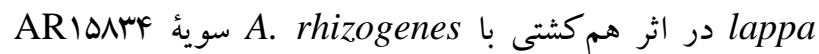
موجب ازدسترفتن شادابى و كاهش توانيى تكثير سلولى

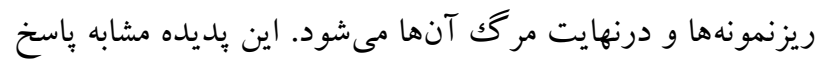

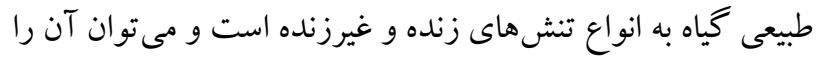

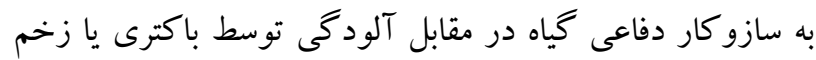

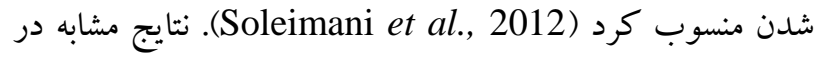
هم كشتى گياه Phalaenopsis violacea با باكترى-Agr obacterium tumefaciens

است (Sreeramanan et al., 2008). در مطالعه حاضر، فقط ريزنمونهاى بركى توانستند ريشهُ مويين توليد كنند. در بررسى القاى ريشهُ مويين در دو كياه از تيره بادمجانيان (Solanaceae) نيز مشاهده شد كه قطعات ساقه و

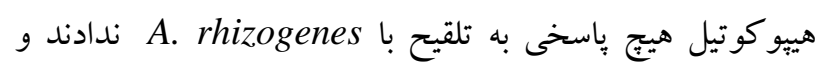
تشكيل ريشه مويين فقط در ريزنمونه بر كى مشاهده شد ( Maheshwari, 2004

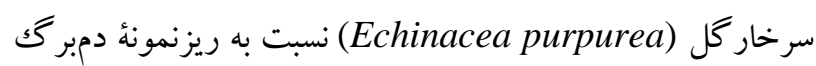
از استعداد بيشترى براى توليد ريشههاى مويين برخوردارند كه با نتايج مطالعئ حاضر در توافقاند. (Wang et al., 2006)

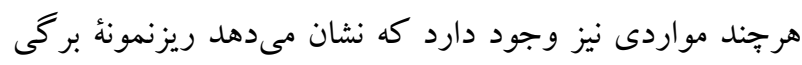

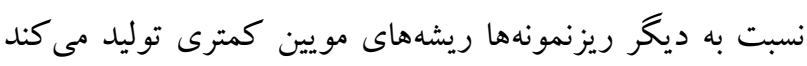
(Brijwal \& Tamta, 2015; Lee et al., 2007) وضعيت فيزيولوزيكى، سنت DNA و تقسيم سلولى در بافت
حدود Y ب-9 روز پِ بساز تلقيح ريزنمونهها با باكترى، از محل

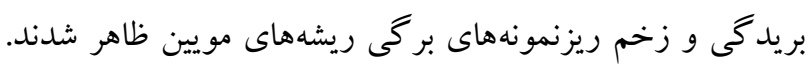

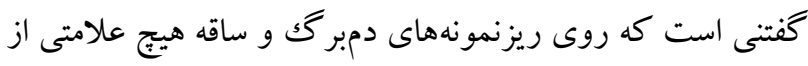

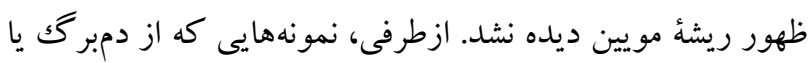

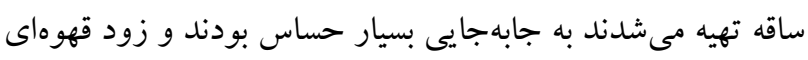

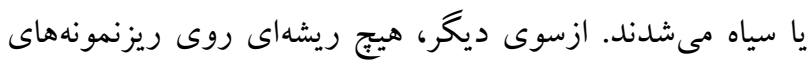

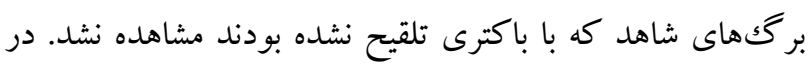

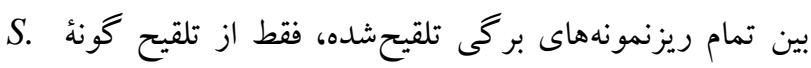
reuterana

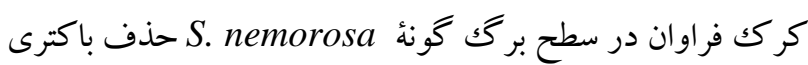

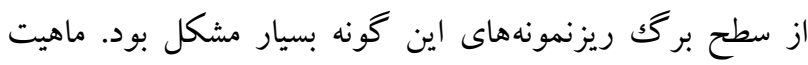

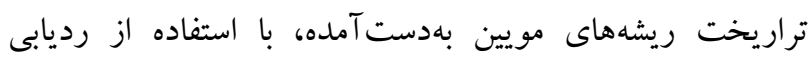

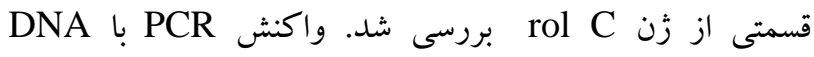

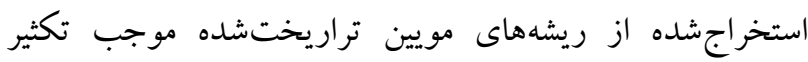
قطعاتى با طول حدود وهاه جفت باز شد، ولى اين زن در DNA

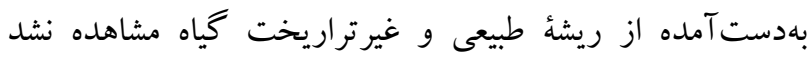

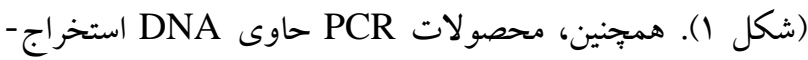

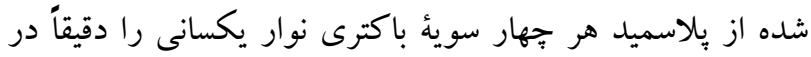
همان محل و اندازه ايجاد كردند، كه حضور T-DNA يلاسميدهاى باكتريايى در زنوم ريشههاى مويين را تأييد مى كند. براساس

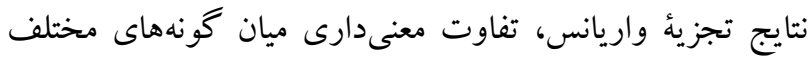

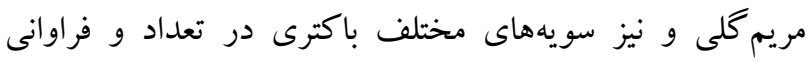

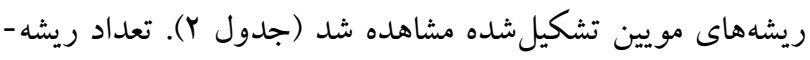
هاى مويين تشكيلشده و فراوانى ريشهزايى بهطور معنىدارى

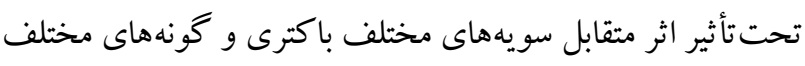

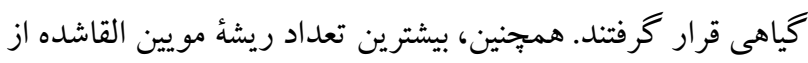

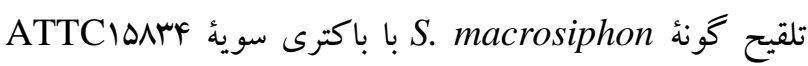

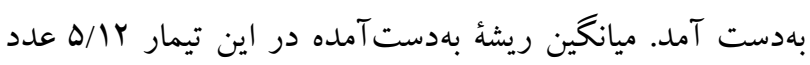
ريشه بهازاى هر جداكشت بركى بود. بيشترين تعداد ريشهُ مويين

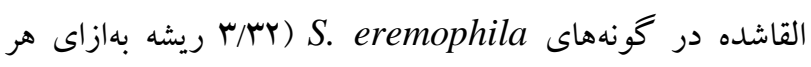
ريزنمونه) و S. reuterana (r/ar ريشه بهازاى هر ريزنمونه) در

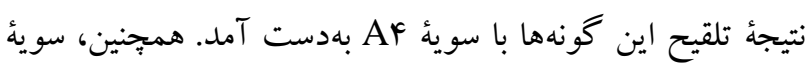

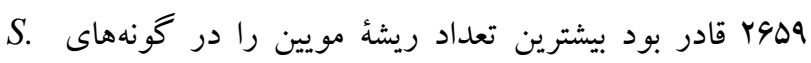
S. nemorosa multicaulis 


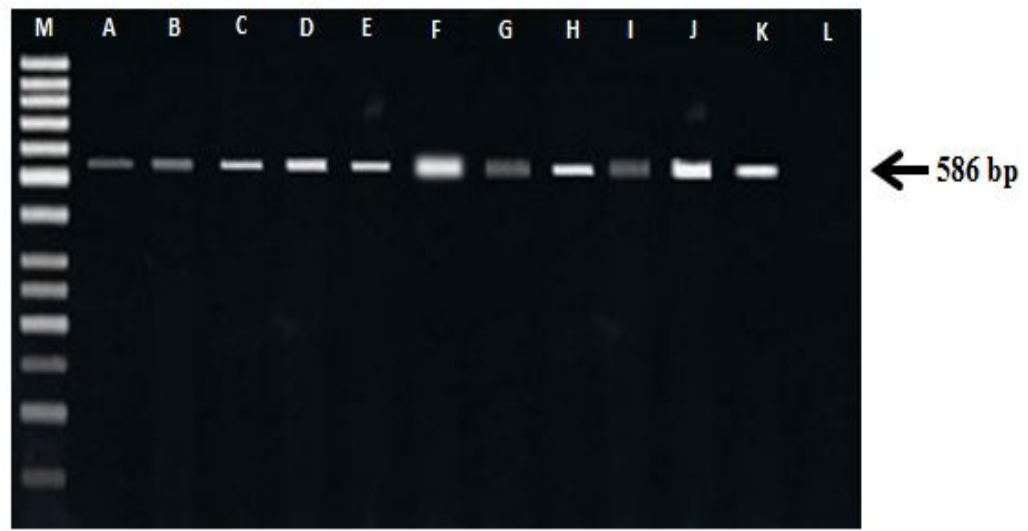

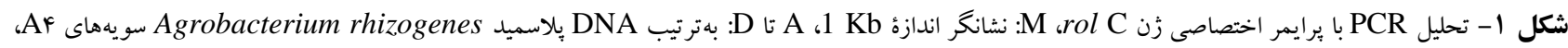

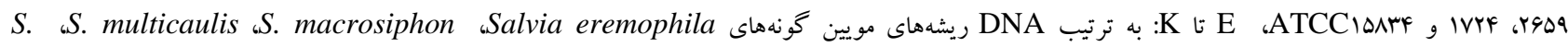

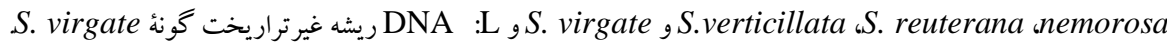

Fig. 1. PCR detection of rol C genes, M: DNA molecular weight (1 Kb), A-D: plasmid of different Agrobacterium rhizogenes strain including: A4, 2659, 1724 and ATCC15834, E-F: DNA of different species hairy roots including: Salvia eremophila, S. macrosiphon, S. multicaulis, S. nemorosa, S. verticillata and S. virigata and L: non-transformed roots of $S$. virigata.

$$
\text { جدول r- تجزية واريانس اثر سويههاى مختلف باكترى بر ريشهزايى گونهاى مختلف مريم كلى. }
$$

Table 2. ANOVA of effect of different bacteria strain on hairy root induction in different Salvia species.

\begin{tabular}{|c|c|c|c|}
\hline فراوانى ريشهزايى & تعداد ريشه به ازاى هر ريزنمونه & درجهُ آزادى & منابع تغييرات \\
\hline $11 \mathrm{V \Lambda} * *$ & V/ar ** & 4 & كونهُ كياهى \\
\hline $19 \vee 9 / Y^{*}$ & $19 / \Upsilon 9 * *$ & $r$ & باكترى \\
\hline $\boldsymbol{I r} \cdot \mathrm{V} / \boldsymbol{r}^{* *}$ & $\Lambda / V V^{* *}$ & 11 & كونهُ كياهى × باكترى \\
\hline Fr. & $4 / .1$ & $11 \%$ & خطا \\
\hline
\end{tabular}

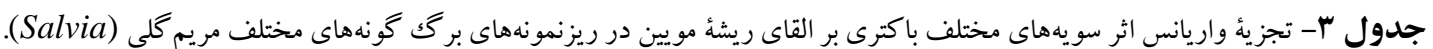
Table 3. ANOVA of effect of different bacteria strain on hairy root induction in leaf explants of different Salvia species.

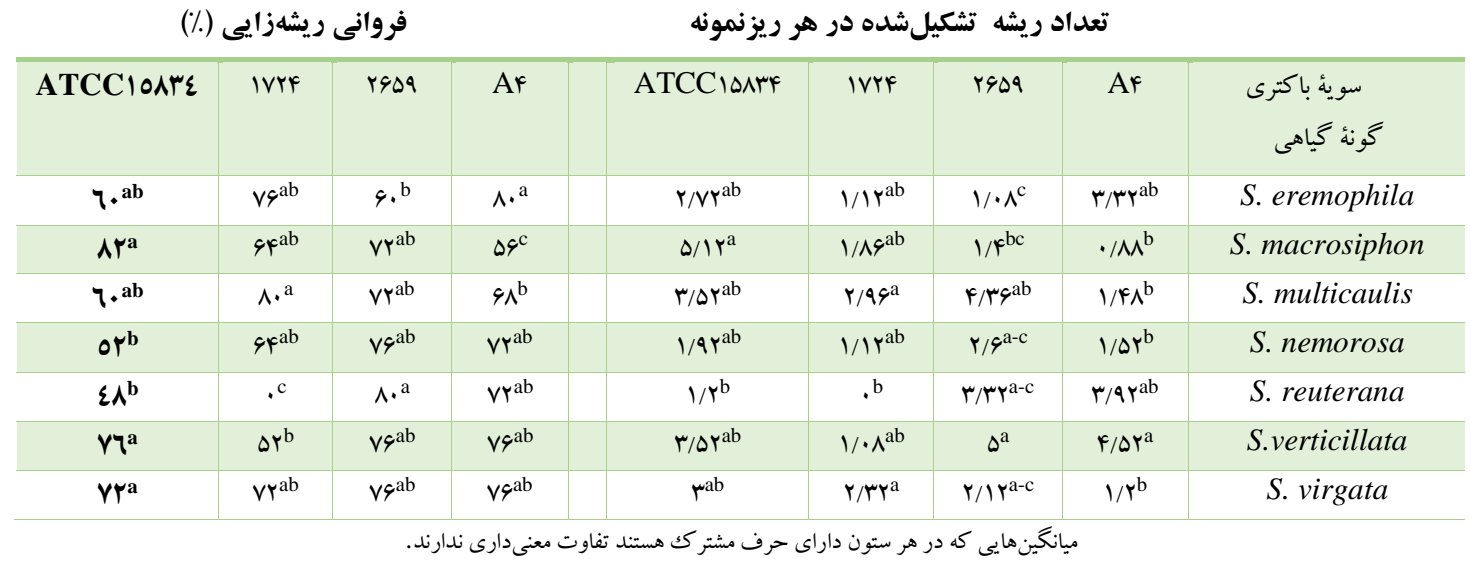

There is no statically difference at $p<0.05$ between means with the same letter. 
تاكسى صورت مى يذيرد، در گام بعدى، نوع رسيتورهاى ديواره

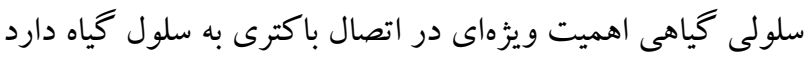
(Tepfer, 1990). ازطرفى بيانشدن زنهاى توالى مرزى راست

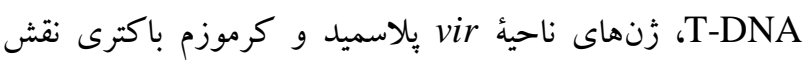

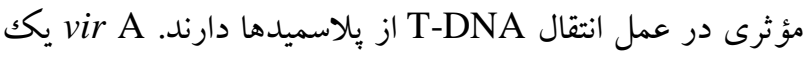

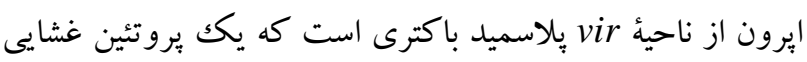

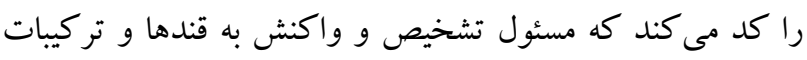

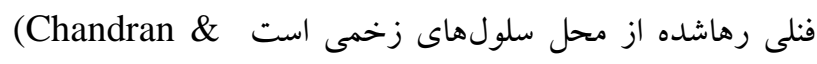

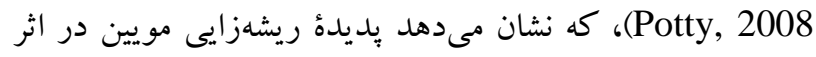

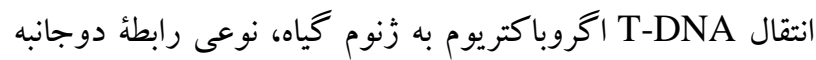

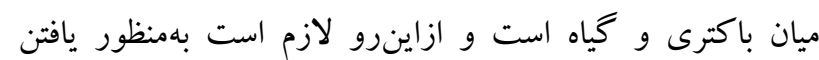

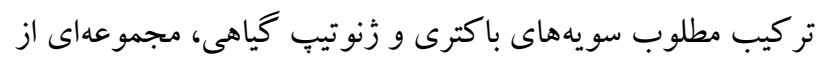
سويههاى باكتريايى بر روى زنوتيٍ مورد نظر آزمون شوند.

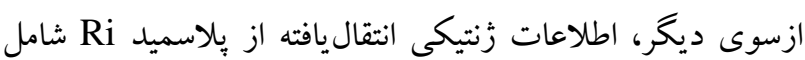

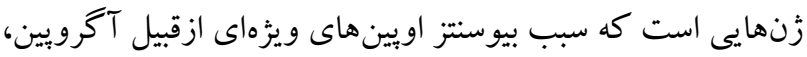

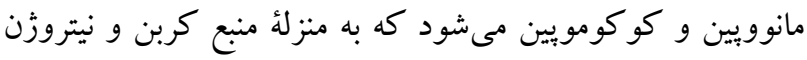

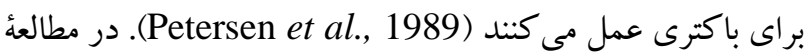
حاضر، دو سوية ATCCIDAFF و Af از نوع آكرويينى

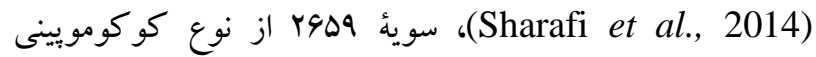
و سوئ (Combard \& Baucher, 1988) ميكومويينى (Tanaka et al., 1994) بود. برخى مطالعات نشان -

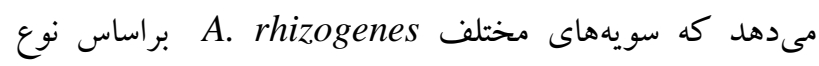
اويين ساختهشده در بافت تراريختشده توسط آنها، توانايىهاى

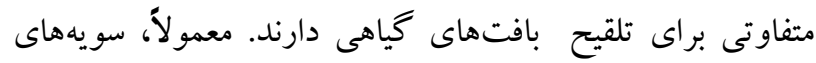
آگرويينى توانايى بيشترى در تلقيح بافتهاى كياهى باهى دارند (Dessaux et al., 1993; Slightom et al., 1986)

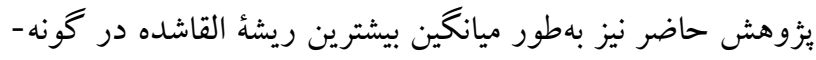

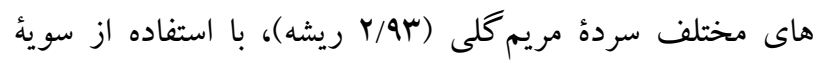
ATCCIOAFF

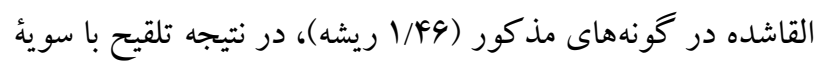
- IVYF

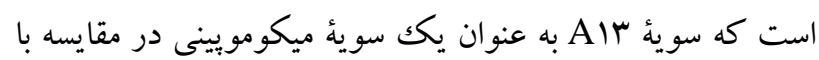

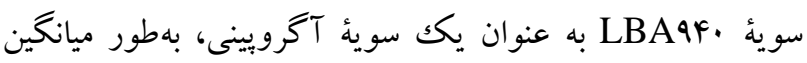

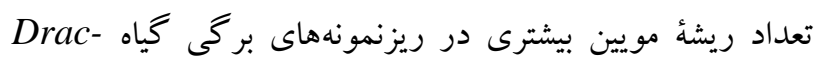
ocephalum kotschyi
هاى مختلف، ممكن است دليل توانايى متفاوت آنها براى توليد

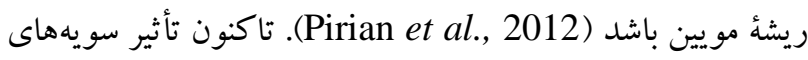
مختلف A. rhizogenes بر القاى ريشٔ مويين در بسيارى از كياهان مطالعه شده است. هر گونهُ خياهى داراى ساختار ديوارة

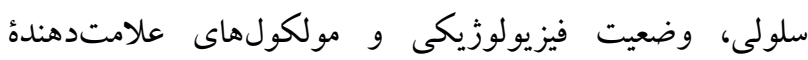

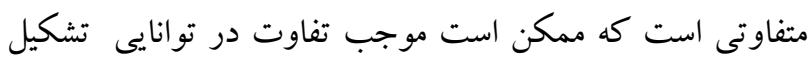
ريشٔ مويين در كونههاى مختلف باشد ( Kuzovkina \& .(Schneider, 2006 همجنين، توالى زنوم باكتريايى و بِلاسميدى نقش بهسزايى در

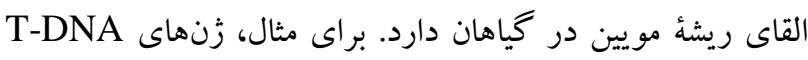

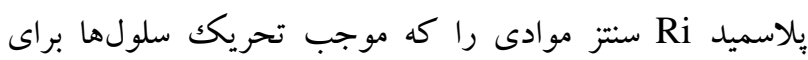
تمايزيابى به سمت توليد ريشه مىشوند برعهده دارند. عمل

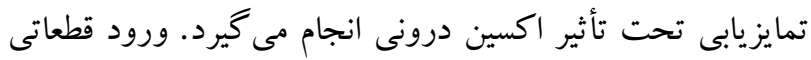

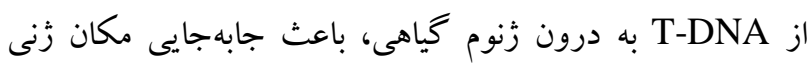
مخصوص بيوسنتز اكسين مىشود. بنابراين، سطح اكسين اين

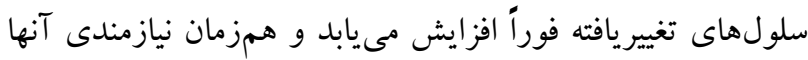

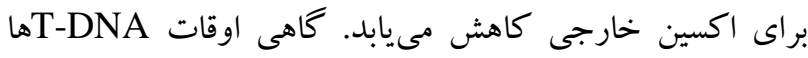
شامل زنهاى tms است كه مستقيماً سبب سنتز اكسين و القاى ريشه مىشوند (Tao \& Li, 2006). همجنين، مشخص شده است كه انتقال و بيان بايدار انواع زنهاى rol نقش بهسز ايى در توليد و سرعت رشد ريشهايى مويين دارند، زيرا موجب افزايش حساسيت سلولها به اكسينهاى درونزاد مىشوند (-Bonh(omme et al., 2000 سويههاى مختلف A. rhizognes ازنظر

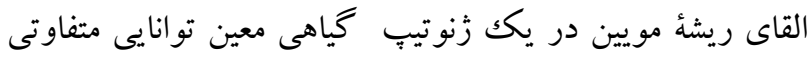
(Christensen et al., 2009; Ercan et al., 1999; دارندين Mahesh \& Jeyachandran, 2011

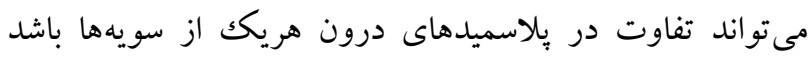
.(Nguyen et al., 1992; Vanhala et al., 1995) در اين بزوهش، اثر متقابل معنىدارى ميان گونهاى مختلف

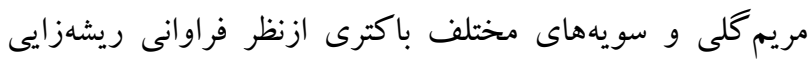

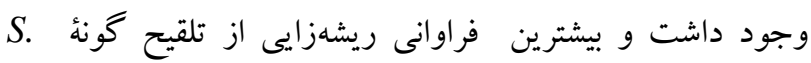
macrosiphon

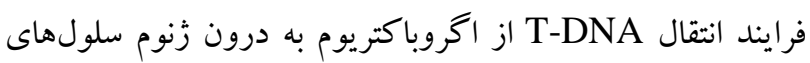
كياه ميزبان مستلزم مشار كت باكترى و سلول گياهى است. هر جند آند

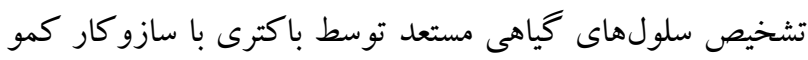




\section{REFERENCES}

Barrett, S.C.H., Wilken, D.H. and Cole, W.W. 2000. Heterostyly in the Lamiaceae: the case of Salvia brandegeei. - Plant Syst. Evol. 223: 211-219.

Bonhomme, V., Laurain-Mattar, D. and Fliniaux, M.A. 2000. Effects of the rol C gene on hairy root: induction development and tropane alkaloid production by Atropa belladonna. - J. Nat. Prod. 63: 1249-1252.

Brijwal, L. and Tamta, S. 2015. Agrobacterium rhizogenes mediated hairy root induction in endangered Berberis aristata DC. - Springer Plus 4: 443-453.

Bulgakov, V.P. 2008. Functions of rol genes in plant secondary metabolism. - Biotechnol. Adv. 26: 318-324.

Chandran, R.P. and Potty, V. 2008. Induction of hairy roots through the mediation of four strains of Agrobacterium rhizogenes on five host plants. - IJBT 7: 129132.

Chaudhuri, K.N., Ghosh, B., Tepfer, D. and Jha, S. 2005. Genetic transformation of Tylophora indica with Agrobacterium rhizogenes A4: growth and tylophorine productivity in different transformed root clones. - Plant Cell Rep. 24: 25-35.

Christensen, B., Sriskandarajah, S., Müller, R. 2009. Transformation of Hibiscus rosa-sinensis L. by Agrobacterium rhizogenes. - J. Hortic. Sci. Biotechnol. 84: 204-208.

Combard, A. and Baucher, M.F. 1988. A common organization of the T-DNA genes expressed in plant hairy roots induced by different plasmids of Agrobacterium rhizogenes. - Plant Mol. Biol. 10: 499-509.

Dessaux, Y., Petit, A. And Tempe, J. 1993. Chemistry and biochemistry of opines, chemical mediators of parasitism. - Phytochem. 34: 31-38.

Doyle, J.J. and Doyle, J.L. 1987. A rapid DNA isolation procedure for small quantities of fresh leaf tissue. - Phytochem. Bull. 19: 11-15.

Ercan, A.G., Taşkin, K.M., Turgut, K. and Yüce, S. 1999. Agrobacterium rhizogenes-mediated hairy root formation in some Rubia tinctorum L. populations grown in Turkey. - Turk. J. Bot. 23: 373-378.

Hu, Z.B. and Du, M. 2006. Hairy Root and its application in plant genetic engineering. - J. Integr. Plant Biol. 48: 121-127.

Hussain, M.S., Fareed, S., Ansari, S., Rahman, M.A., Ahmad, I.Z. and Saeed, M. 2012. Current approaches toward production of secondary plant metabolites. - J. Pharm. Bioall. Sci. 4: 10-20.

Kamatou, G.P., Makunga, N.P., Ramogola, W.P. and Viljoen, A.M. 2008. South African Salvia species: a review of biological activities and phytochemistry. - J. Ethnopharmacol. 119: 664-672.

Kumar, V., Sharma, A., Prasad. B.C.N, Gururaj, H.B. and Ravishankar, G.A. 2006. Agrobacterium rhizogenes mediated genetic transformation resulting in hairy root formation is enhanced by ultrasonication and acetosyringone treatment. - Electron. J. Biotechnol. 9: 349-357.

$$
\begin{aligned}
& \text { طوركلى، بهنظر مىرسد نوع گونهُ گياهى، ريزنمونه و سوية } \\
& \text { باكتريايى مورد استفاده نقش بهسزايى در ميزان القاى ريشهُ مويين } \\
& \text { در سردة مريم كلى دارد. } \\
& \text { نتيجه كيرى نهايى }
\end{aligned}
$$$$
\text { امروزه، بهره گيرى از كشت ريشه هاى مويين كياهان دارويى }
$$$$
\text { جهت توليد تركيبات ارزشمند دارويى اهميت ويزهاى ييدا كرده }
$$$$
\text { است. معمولاً توانايى ايجاد ريشٔ مويين توسط سويههاى مختلف }
$$$$
\text { A. rhizogenes }
$$$$
\text { ريشههاى مويين يافتن مناسبترين سويةٔ باكترى و بهترين نوع }
$$$$
\text { ريزنمونه گياهى جهت ايجاد ريشه مويين در گونهاى گياهى }
$$$$
\text { است. در اين مطالعه، با توجه به اهميت دارويى گياهان سردهُ مريم }
$$

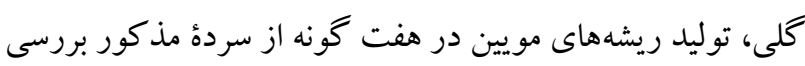$$
\text { شد. سويههاى مختلف باكترى قابليتهاى متفاوتى در القاى ريشٔ }
$$$$
\text { مويين در ريزنمونهاى بركى گونههاى مختلف سردهُ مريم گلى }
$$

S. ma- داشتند و بيشترين فراوانى ريشهزيى از تلقيح كونئ crosiphon مطالعات اندكى كه در زمينهُ القا و كشت ريشههاى مويين اين سرده انجام شده، ئزوهش حاضر نشان مىدهد القا و كشت ريشههاى مويين در كونهاى مختلف سرده مريم كلى جهت توليد متابوليتهاى ثانوية ارزشمند دارويى، بسيار اميدواركننده خواهد

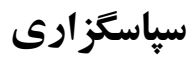

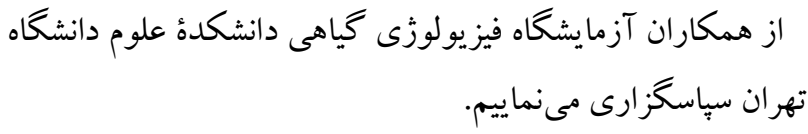


Kuzovkina, I.N. and Schneider, B. 2006. Progress in Botany. - Springer, Berlin, Heidelberg. pp: 275-314.

Lee, S.Y., Xu, H., Kim, Y.K. and Park, S.U. 2007. Rosmarinic acid production in hairy root cultures of Agastache rugosa Kuntze. - World J. Microbiol. Biotechnol. 24: 969-972.

Li, M., Li, Q., Zhang, C., Zhang, N., Cui, Z., Huang, L. and Xiao, P. 2013. An ethnopharmacological investigation of medicinal Salvia plants (Lamiaceae) in China. - Acta Pharm. Sin. 3: 273-280.

Mahesh, A. and Jeyachandran, R. 2011. Agrobacterium rhizogenes-mediated hairy root induction in Taraxacum officinale and analysis of sesquiterpene lactones. - Plant Biosyst. 145: 620-626.

Nguyen, C., Bourgaud, F., Forlot, P. and Guckert, A. 1992. Establishment of hairy root cultures of Psoralea species. - Plant Cell Rep. 11: 424-427.

Pawar, P.K. and Maheshwari, V.L. 2004. Agrobacterium rhizogenes mediated hairy root induction in two medicinally important members of family Solanaceae. IJBT 3: 414-417.

Petersen, S.G., Stummann, B.M., Olesen, P. and Henningsen, K.W. 1989. Structure and function of rootinducing (Ri) plasmids and their relation to tumorinducing (Ti) plasmids. - Physiol. Plant 77: 427-435.

Pirian, K., Piri, K. and Ghiyasvand, T. 2012. Hairy roots induction from Portulaca oleracea using Agrobacterium rhizogenes to noradrenaline's production. - Int. J. Appl. Basic. Sci. 3: 642-649.

Rabban, M., Sajjadi, S.E., Jafarian, A., Vaseghi, G. 2005. Anxiolytic effects of Salvia reuterana Boiss. on the elevated plus-maze model of anxiety in mice. - J. Ethnopharmacol. 101: 100-103.

Rechinger, K.H. 1982. Labiatae Flora Iranica. Akademische Drucku-Verlagsanstalt, Graz, 598 pp.

Sambrook, J. and Russell, D.W. 2001. Molecular Cloning: A Laboratory Manual. - Cold Spring Harbor Laboratory Press, New York, 2344 pp.

Shanks, J.V. and Morgan, J. 1999. Plant 'hairy root' culture. - Curr. Opin. Chem. Biol. 10: 151-155.

Sharafi, A., Sohi, H.H., Azadi, P. and Sharafi, A.A. 2014. Hairy root induction and plant regeneration of medicinal plant Dracocephalum kotschyi. - Physiol. Mol. Biol. Plants 20: 257-262.

Sharma, P., Padh, H. and Shrivastava, N. 2013. Hairy root cultures: a suitable biological system for studying secondary metabolic pathways in plants. - Eng. Life Sci. 13: 62-75.

Slightom, J.L., Durand-Tardif, M., Jouanin, L. and Tepfer, D. 1986. Nucleotide sequence analysis of TLDNA of Agrobacterium rhizogenes agropine type plasmid. Identification of open reading frames. - J. Biol. Chem. 261: 108-121.

Soleimani, T. Keyhanfar, M. Piri, K.H. Hasanloo, T. 2012. Hairy root induction in burdock (Arctium lappa L.). JMP 44: 176-184.

Sreeramanan, S., Vinod, B., Sashi, S. and Xavier, R. 2008. Optimization of the transient Gusa gene transfer of Phalaenopsis Violacea orchid via Agrobacterium Tumefaciens: an assessment of factors influencing the effi- ciency of gene transfer mechanisms. - Adv. Nat. Appl. Sci. 2: 77-89.

Tanaka, N., Ikeda, T. and Oka, A. 1994. Nucleotide sequence of the rol region of the mikimopine-type rootinducing plasmid pRi1724. - Biosci. Biotechnol. Biochem. 58: 548-551.

Tao, J. and Li, L. 2006. Genetic transformation of Torenia fournieri L. mediated by Agrobacterium rhizogenes. Afr. J. Bot. 72: 211-216.

Tepfer, D. 1990. Genetic transformation using Agrobacterium rhizogenes. - Physiol. Plant. 79: 140-146.

Vanhala, L., Hiltunen, R. and Oksman-Caldentey, K.M. 1995. Virulence of different Agrobacterium strains on hairy root formation of Hyoscyamus muticus. - Plant Cell Rep. 14: 236-240.

Wang, B., Zhang, G., Zhu, L., Chen, L. and Zhang, Y. 2006. Genetic transformation of Echinacea purpurea with Agrobacterium rhizogenes and bioactive ingredient analysis in transformed cultures. - Colloids Surf. B Biointerfac. 53: 101-104.

How to cite this article:

Norouzi, R., Babalar, M. and Mirmasoumi, M. 2017. Investigation of hairy root induction in some Salvia L. species. - Nova Biologica Rep. 4: 173-180.

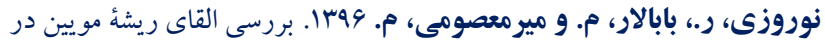

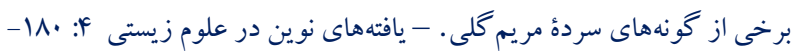

$$
\begin{aligned}
& \text {. IV }
\end{aligned}
$$

